\title{
Efficient Chemoenzymatic Synthesis of Pelitrexol via Enzyme Differentiation of a Remote Stereocenter
}

\author{
Shanghui Hu, ${ }^{*}$ Sean Kelly, Steve Lee, Junhua Tao, \\ Eric Flahive \\ Pfizer Global Research and Development - Chemical Research and \\ Development, 10578 Science Center Drive, La Jolla, California 92121 \\ Shanghui.Hu@pfizer.com
}

\section{Section I. Experimental procedures and characterization data}

Enzyme screening. A screening kit was thawed for 5 minutes and $80 \mu \mathrm{L}$ of potassium phosphate buffer ( $0.1 \mathrm{M}, \mathrm{pH} 7.0)$ was then dispensed into each well via a multi-channel pipette. $10 \mu \mathrm{L}$ of ACN solution of the substrate $(10-20 \mathrm{mg}$ of substrate/mL) was then added to each well, and the plate was incubated at $23{ }^{\circ} \mathrm{C}$ on a thermomixer $(900 \mathrm{rpm}$ ). The reactions were quenched with $100 \mu \mathrm{L}$ of acetonitrile after $5 \mathrm{~h}$. The 96 -well plate was then centrifuged, and the supernatant was transferred from each well into another 96-well plate and analyzed with automated HPLC using a short $\mathrm{C}_{18}$ column $(30 \times 4.6 \mathrm{~mm}, 3 \mu \mathrm{m})$ and $\mathrm{ACN} / \mathrm{H}_{2} \mathrm{O}$ containing $0.1 \%$ TFA as the solvent system.

Preparation of compound 3. To a 3L Morton flask was charged compound 3 ( 40 g, 89.5 $\mathrm{mmol})$ in $500 \mathrm{~mL}$ of chloroform. After cooling down to $0{ }^{\circ} \mathrm{C}$, triethylamine $(37.3 \mathrm{~mL}$, $268.4 \mathrm{mmol}$ ) was added while stirring vigorously. Ethyl chlorooxoacetate $(29.9 \mathrm{~mL}, 89.5$ mmol) in $233 \mathrm{~mL}$ of chloroform was added dropwise to the stirring reaction mixture during 1-2 $\mathrm{h}$. The reaction was monitored by HPLC. After $2-4 \mathrm{~h}$, the reaction was quenched by $50 \mathrm{~mL}$ of methanol and further stirring for another $2 \mathrm{~h}$. After removal of the solvents, the crude product was recrystallized in heptane/ethyl acetate $(10: 1,500 \mathrm{~mL})$. The formed solid was filtered and dried in oven to give 9 (45 g, 90\%). Compound 9 : 
HRESI m/z: $[\mathrm{M}+\mathrm{H}]^{+}$547.2254. ${ }^{1} \mathrm{H}$ NMR $\left(300 \mathrm{MHz}, \mathrm{CDCl}_{3}\right): \delta 7.72(\mathrm{~s}, 1 \mathrm{H}), 7.50(\mathrm{~s}, 1 \mathrm{H})$, 4.30 (dd, $J=7.2,14.1 \mathrm{~Hz}, 4 \mathrm{H}), 4.15$ (br dd, $J=2.1,12.9 \mathrm{~Hz}, 2 \mathrm{H}), 3.30$ (dd, $J=9.0,12.9$ $\mathrm{Hz}, 1 \mathrm{H}), 2.79-2.92(\mathrm{~m}, 2 \mathrm{H}), 2.24(\mathrm{t}, J=8.7 \mathrm{~Hz}, 1 \mathrm{H}), 2.24(\mathrm{t}, J=8.7 \mathrm{~Hz}, 1 \mathrm{H}), 2.16(\mathrm{~s}$, $3 \mathrm{H}), 2.04(\mathrm{~m}, 1 \mathrm{H}), 1.69-1.86(\mathrm{~m}, 2 \mathrm{H}), 1.36(\mathrm{q}, \mathrm{J}=7.2 \mathrm{~Hz}, 3 \mathrm{H}), 1.29$ (s, 9H). ${ }^{13} \mathrm{C} \mathrm{NMR}$ (75 ppm, $\left.\mathrm{CDCl}_{3}\right) \delta 206.28,179.46,161.88,161.72,160.38,160.31,150.77,146.61$, $145.07,135.64,128.72,101.57,61.38,60.29$, 45.38, 39.72, 33.33, 30.37, 30.29, 26.40, $25.63,25.08,13.77,13.67,13.61,13.50,13.03$.

Preparation of $(S)$-acid 12. Chirazyme L-2 solution (200 mL, from Biocatalytics, Inc) was mixed with citric buffer $(450 \mathrm{~mL}, 0.5 \mathrm{M}, \mathrm{pH} 4.2)$. To the stirred mixture, oxalamic ester 9 (30 g, $5.48 \mathrm{mmol})$ in $300 \mathrm{~mL}$ of DMF was added. The mixture was stirred gently (about $100-150 \mathrm{rpm}$ ) at $23{ }^{\circ} \mathrm{C}$. The reaction was stopped after $45 \%$ of conversion $(6-8 \mathrm{~h})$, the following work-up procedure was performed for the isolation of $(S)$-acid 12. The precipitate was recovered by centrifuge and was washed with distilled $\mathrm{H}_{2} \mathrm{O}(0.1 \mathrm{~L})$; the supernatant was extracted with $\operatorname{MTBE}\left(0.5 \mathrm{~L}\right.$, twice) at cold temperature (about $5{ }^{\circ} \mathrm{C}$ to $10{ }^{\circ} \mathrm{C}$ ); and the aqueous layer was stored at $0{ }^{\circ} \mathrm{C}-5{ }^{\circ} \mathrm{C}$ for the future re-use. The combined MTBE layer and the precipitate were washed with phosphate buffer $(0.3 \mathrm{~L}$, twice, $\mathrm{pH} 7.0$, $0.1 \mathrm{M})$, respectively. The $\mathrm{pH}$ of the aqueous layer was kept at 7.0. The organic layer was further washed with phosphate buffer $(\mathrm{pH} 8.0,0.02 \mathrm{mM}, 0.5 \mathrm{~L}$, twice). After drying over $\mathrm{Na}_{2} \mathrm{SO}_{4}$, the solvent was removed in vacuo to afford the remaining $(R)$-ester $9(16.5 \mathrm{~g}$, $55 \%$ ), which was racemized by the following dehydrogenation and hydrogenation procedure. The combined aqueous layers was adjusted quickly to a $\mathrm{pH}$ of 7.0 and extracted with EtOAc (0.5 L, 3 times). After drying over $\mathrm{Na}_{2} \mathrm{SO}_{4}$, and removal of the solvents, optical pure $(S)$-acid 12 (11.9 g, 42\%, 94\% ee, 96\% purity) was afforded and the optical purity was enhanced to $>97 \%$ ee by recrystallization in heptane/ethyl acetate. The $e e$ of compounds 9 and $\mathbf{1 2}$ were analyzed by chiral HPLC using a Chiracel AS-RH column (150 mm x $4.6 \mathrm{mmm}, 5 \mu)$, mobile phase: ACN/ $\mathrm{H}_{2} \mathrm{O}(60: 40,0.1 \%$ TFA), 0.7 $\mathrm{mL} / \mathrm{min}$, detection at $254 \mathrm{~nm}$. Compound 12: HRESI m/z: $[\mathrm{M}+\mathrm{H}]^{+}$519.1895. ${ }^{1} \mathrm{H} \mathrm{NMR}$ $\left(300 \mathrm{MHz}, \mathrm{CDCl}_{3}\right): \delta 8.20(\mathrm{~s}, 1 \mathrm{H}), 7.56(\mathrm{~s}, 1 \mathrm{H}), 4.30(\mathrm{dd}, J=6.9,14.1 \mathrm{~Hz}, 2 \mathrm{H}), 4.13(\mathrm{~d}$, $J=12.6 \mathrm{~Hz}, 1 \mathrm{H}), 3.30(\mathrm{dd}, J=9.3,12.6 \mathrm{~Hz}, 1 \mathrm{H}), 2.83-2.86(\mathrm{~m}, 3 \mathrm{H}), 2.26(\mathrm{t}, J=8.4 \mathrm{~Hz}$ 1H), 2.17 (s, 3H), $2.05(\mathrm{~m}, 1 \mathrm{H}), 1.67-1.83(\mathrm{~m}, 2 \mathrm{H}), 1.38$ (t, J = 7.2 Hz, 3H), $1.30(\mathrm{~s}, 9 \mathrm{H})$. 
${ }^{13} \mathrm{C}$ NMR $\left(75 \mathrm{MHz}, \mathrm{CDCl}_{3}\right) \delta .180 .50,166.95,162.87,161.57,161.45,151.98,147.92$, $147.68,138.06,135.17,128.87,102.64,62.53$, 46.46, 40.80, 34.33, 31.52, 27.31, 26.67, 26.30, 14.56, 14.10.

Racemization of $(\boldsymbol{R})$-enantiomer 9. Compound $(R)-9(5 \mathrm{~g}, 9.16 \mathrm{mmol}, 65 \%$ ee $)$ in methanol $(50 \mathrm{~mL})$ was refluxed at $80{ }^{\circ} \mathrm{C}$ for $10 \mathrm{~h}$. After cooling, methanol was removed and the crude product was washed with MTBE (100 mL, twice), phosphate buffer (pH 7.0, $100 \mathrm{~mL})$, and distilled water. After drying in oven overnight, $(R)-\mathbf{3}$ was afforded in $88 \%$ (3.6 g). ${ }^{1} \mathrm{H}$ NMR (DMSO- $\left.d_{6}, 700 \mathrm{MHz}\right): 1.21(\mathrm{~s}, 9 \mathrm{H}, t-\mathrm{Bu}) ; 1.27(\mathrm{t}, J=7.0 \mathrm{~Hz}, 3 \mathrm{H}$, $\left.\mathrm{CH}_{2} \mathrm{CH}_{3}\right) ; 1.57\left(\mathrm{~m}, 1 \mathrm{H}, \mathrm{CH}_{2}\right) ; 1.63\left(\mathrm{~m}, 1 \mathrm{H}, \mathrm{CH}_{2}\right) ; 1.95(\mathrm{dd}, J=9.1 \mathrm{~Hz}, J=15.4 \mathrm{~Hz}, 1 \mathrm{H}$, $\left.\mathrm{CH}_{2}\right) ; 2.15\left(\mathrm{~s}, 3 \mathrm{H}, \mathrm{CH}_{3}\right) ; 2.56\left(\mathrm{dd}, J=3.5 \mathrm{~Hz}, J=15.4 \mathrm{~Hz}, 1 \mathrm{H}, \mathrm{CH}_{2}\right) ; 2.81-2.91(\mathrm{~m}, 3 \mathrm{H})$; $3.29(\mathrm{~m}, 1 \mathrm{H}) ; 4.23$ (quart, $\left.J=7.0 \mathrm{~Hz}, 2 \mathrm{H}, \mathrm{CH}_{2} \mathrm{CH}_{3}\right) ; 6.48$ (s, $\left.1 \mathrm{H}, \mathrm{NH}\right) ; 7.54$ (s, 1H, CH); 10.58 (s, 1H, NH); 11.2 (s, 1H, NH). ${ }^{13} \mathrm{C}$ NMR (DMSO- $\left.d_{6}\right): 13.17,14.19,25.26,25.29$, 26.27, 29.97, 33.82, 40.04, 45.03, 60.56, 87.22, 127.94, 134.28, 136.24, 147.01, 148.83, 158.19, 159.41, 161.37, 181.11.

To $(R)-3(3 \mathrm{~g}, 6.72 \mathrm{mmol})$ in methylene chloride $(150 \mathrm{~mL})$ was added 2,3-dichloro5,6-dicyano-1,4-benzoquinone $(2.4 \mathrm{~g}, 14.78 \mathrm{mmol})$ while stirring vigorously. After $2 \mathrm{~h}$, the mixture was washed with aqueous $\mathrm{NaHCO}_{3}$, then brine, dry over $\mathrm{MgSO}_{4}$ to give the desired 14 (2.9 g, 96\%). ESI m/z: $[\mathrm{M}+\mathrm{H}]^{+}$443.2. ${ }^{1} \mathrm{H}$ NMR (300 MHz, DMSO-d6, 300 MHz): $\delta$ 12.26, (s, 1H), 11.33 (s, 1H), 8.70 (s, 1H), 7.49 (s, 1H), 4.22 (q, J = 7.2 Hz, 2H), 3.09 (m, 2H), 2.50 (m, 2H), 2.04 (s, 3H), $1.26(9 \mathrm{H}), 1.25$ (t, J = 7.2 Hz, 3H).

In a hydrogenator vessel, $14(2.5 \mathrm{~g}, 5.64 \mathrm{mmol})$ in acetic acid $(25 \mathrm{~mL})$ was charged a slurry of $5 \% \mathrm{Pd} / \mathrm{C}$ in acetic acid $(4 \mathrm{~mL})$. Following the nitrogen purges, the reactor was charged with hydrogen at 50 psi hydrogen gas. The reaction mixture was slowly heated to $75{ }^{\circ} \mathrm{C}$ and agitated at $700 \mathrm{rpm}$. The reaction was held overnight $(\sim 16 \mathrm{~h})$ at $75{ }^{\circ} \mathrm{C}$ and 50 psi. Typically, after $16 \mathrm{~h}$, the reactor heating was turned off, hydrogen gas in the reactor was drained and replaced with an inert atmosphere, and the reactor was drained and efficiently rinsed with acetic acid. The rinse was combined with the drained and still warm reaction mixture. Next, the catalyst was removed by filtration in as short a time as possible through a short bed of Celite contained in a sintered glass funnel. It is important that the reaction mixture be still warm during the filtration in order to avoid premature 
crystallization of product from acetic acid upon cooling. The filter cake was washed with warm acetic acid. The resulting filtrate was transferred to a Distillation Reactor and concentrated to low volume at 45 to $65{ }^{\circ} \mathrm{C}$. During the distillation of acetic acid, the product began to crystallize as a white solid. Then, acetonitrile was slowly charged to the concentrated product in acetic acid while continuing agitation. This dilution was accompanied by further crystallization of the product. Next, the mixture was cooled to 4 ${ }^{\circ} \mathrm{C}$ with an ice bath for $1.5 \mathrm{~h}$, and the white solid was filtered through a filter funnel, and washed with cold acetonitrile. The filter cake was dried at $50{ }^{\circ} \mathrm{C}$ for 16 hours under vacuum to afford racemic 3 as a white, crystalline solid (95\% yield, 99\% HPLC purity). ${ }^{1} \mathrm{H}$ NMR (DMSO- $\left.d_{6}, 700 \mathrm{MHz}\right): 1.21(\mathrm{~s}, 9 \mathrm{H}, t-\mathrm{Bu}) ; 1.27\left(\mathrm{t}, \mathrm{J}=7.0 \mathrm{~Hz}, 3 \mathrm{H}, \mathrm{CH}_{2} \mathrm{CH}_{3}\right)$; $1.57\left(\mathrm{~m}, 1 \mathrm{H}, \mathrm{CH}_{2}\right) ; 1.63\left(\mathrm{~m}, 1 \mathrm{H}, \mathrm{CH}_{2}\right) ; 1.95\left(\mathrm{dd}, J=9.1 \mathrm{~Hz}, \mathrm{~J}=15.4 \mathrm{~Hz}, 1 \mathrm{H}, \mathrm{CH}_{2}\right) ; 2.15(\mathrm{~s}$, $\left.3 \mathrm{H}, \mathrm{CH}_{3}\right) ; 2.56\left(\mathrm{dd}, J=3.5 \mathrm{~Hz}, J=15.4 \mathrm{~Hz}, 1 \mathrm{H}, \mathrm{CH}_{2}\right) ; 2.81-2.91(\mathrm{~m}, 3 \mathrm{H}) ; 3.29(\mathrm{~m}, 1 \mathrm{H})$; 4.23 (quart, $\left.J=7.0 \mathrm{~Hz}, 2 \mathrm{H}, \mathrm{CH}_{2} \mathrm{CH}_{3}\right) ; 6.48$ (s, 1H, $\left.\mathrm{NH}\right) ; 7.54(\mathrm{~s}, 1 \mathrm{H}, \mathrm{CH}) ; 10.58(\mathrm{~s}, 1 \mathrm{H}$, $\mathrm{NH}) ; 11.2(\mathrm{~s}, 1 \mathrm{H}, \mathrm{NH}) .{ }^{13} \mathrm{C} \mathrm{NMR}\left(\mathrm{DMSO}-d_{6}\right): 13.174,14.192,25.260,25.287,26.270$, 29,974, 33.821, 40.036, 45.031, 60.563, 87.224, 127.942, 134.279, 136.238, 147.008, $148.827,158.191,159.414,161.373,181.105$.

Preparation of compound 13. To $12(3.57 \mathrm{~g}, 6.88 \mathrm{mmol})$ in methylene chloride (150 $\mathrm{mL})$ was added 1-hydroxybenzotriazole $(1.15 \mathrm{~g}, 8.94 \mathrm{mmol})$ and 1-[3(dimethylamino)propyl]-3-ethylcarbodiimide hydrochloride (1.62 g, $8.94 \mathrm{mmol})$ while stirring vigorously. After 1h, L-glutamate-di-OEt (2.35 g, $10.32 \mathrm{mmol})$ and triethylamine $(1.8 \mathrm{~mL}, 13.76 \mathrm{mmol})$ were added at $0{ }^{\circ} \mathrm{C}$. Then the mixture was warmed to room temperature and stirred for $30 \mathrm{~min}$ to $1 \mathrm{~h}$. The reaction mixture was washed with saturated $\mathrm{NaHCO}_{3}$ (three times), $1 \mathrm{~N} \mathrm{HCl}$ (three times), brine (three times), and dried over $\mathrm{MgSO}_{4}$ to afford 13 (4.6 g, 96\%, 99\% ee and 98\% chemical purity). The ee and de of compound 13 were analyzed by chiral HPLC using a Chiracel AS-RH column (150 mm x $4.6 \mathrm{mmm}, 5 \mu)$; mobile phase: $\mathrm{ACN} / \mathrm{H}_{2} \mathrm{O}(60: 40,0.1 \% \mathrm{TFA}), 0.7 \mathrm{~mL} / \mathrm{min}$, detection at $254 \mathrm{~nm}$. HRESI m/z: $[\mathrm{M}+\mathrm{H}]^{+}$704.2959. ${ }^{1} \mathrm{H}$ NMR $\left(300 \mathrm{MHz}, \mathrm{CDCl}_{3}\right): \delta .8 .34(\mathrm{~s}, 1 \mathrm{H})$, $6.76(\mathrm{~d}, J=7.6 \mathrm{~Hz}, 1 \mathrm{H}), 4.72(\mathrm{~m}, 1 \mathrm{H}), 4.07-4.40(\mathrm{~m}, 6 \mathrm{H}), 3.32(\mathrm{dd}, J=12.3 \mathrm{~Hz}, 1 \mathrm{H})$, 2.76-2.90 (m, 2H), 2.00-2.2.55 (m, 8H), $1.74(\mathrm{~m}, 2 \mathrm{H}), 1.15-1.40(\mathrm{~m}, 9 \mathrm{H}), 1.28(\mathrm{~s}, 9 \mathrm{H})$. ${ }^{13} \mathrm{C}$ NMR $\left(75 \mathrm{MHz}, \mathrm{CDCl}_{3}\right) \delta$ 180.46, 173.48, 172.26, 162.85, 162.08, 161.27, 151.69, 
$147.60,143.97,134.46,133.75,132.02,102.53,62.33,62.05,61.10,52.53,46.30,40.65$, $34.35,31.29,30.82,27.74,27.33,27.15,26.55,25.88,14.48,14.41,14.03$.

Preparation of compound 1. Compound 13 (3.3 g, 4.69 mmol) dissolved in $\mathrm{MeOH}$ (10 $\mathrm{mL}$ ) was stirred with aqueous sodium hydroxide solution $(150 \mathrm{~mL}, 1 \mathrm{M})$ at room temperature for overnight. After removal of $\mathrm{MeOH}$, the $\mathrm{pH}$ of the reaction solution was adjusted to 3.0 with $4 \mathrm{~N} \mathrm{HCl}$ at $0{ }^{\circ} \mathrm{C}$. The precipitate was washed with distilled water and acetonitrile, and dried in oven to afford $\mathbf{1}$ (2.1 g, 97\%, 98\% chemical purity, >98\% de and ee). ESI m/z: $[\mathrm{M}+\mathrm{H}]^{+}$462.0. ${ }^{1} \mathrm{H}$ NMR $\left(300 \mathrm{MHz}, \mathrm{D}_{2} \mathrm{O}\right): \delta .35$ (s, $\left.1 \mathrm{H}\right), 4.19(\mathrm{dd}, J=4.9$, $8.7 \mathrm{~Hz}, 1 \mathrm{H}), 3.20(\mathrm{~d}, J=10.7 \mathrm{~Hz}, 1 \mathrm{H}), 2.80(\mathrm{dd}, J=8.7,12.8 \mathrm{~Hz}, 1 \mathrm{H}), 2.66(\mathrm{t}, \mathrm{J}=8.3$ $\mathrm{Hz}, 2 \mathrm{H}), 2.43$ (dd, $J=4.0,15.6 \mathrm{~Hz}, 1 \mathrm{H}), 2.22$ (t, $J=8.3 \mathrm{~Hz}, 2 \mathrm{H}$ ), 2.00 (s, 3H), 1.81-2.12 (m, 4H), 1.60 (brs, 1H), $1.48(\mathrm{~m}, 2 \mathrm{H}){ }^{13} \mathrm{C}$ NMR $\left(75 \mathrm{MHz}, \mathrm{D}_{2} \mathrm{O}\right) \delta .182 .55,179.31$, $164.30,160.83,153.83,145.92,135.11,132.88,132.36,84.05,56.18,45.26,34.61$, $33.88,30.32,28.78,25.50,24.80,13.14$. 